\title{
GENDER DIFFERENCES IN FRUIT PRODUCTION AND SELECTION OF AVOCADO AND BANANA VARIETIES: CASE STUDY AT WONDO GENET AND WONDO WOREDAS, SOUTHERN ETHIOPIA
}

\author{
aTamirat G. Feyisa, ${ }^{b}$ Habtamu G. Megersa* \\ a Socio-economic department, Ethiopian Agricultural Research Institute: Wondo Genet Agricultural Research Center, Ethiopia. \\ ${ }^{b}$ Horticulture department, Ethiopian Agricultural Research Institute: Wondo Genet Agricultural Research Center, Ethiopia.
}

\section{ART ICLE INF O}

\section{Article history}

Received: January 28, 2020

Revised: July 31, 2020

Accepted: August 19, 2020

\section{Keywords}

Farming activities

Females

Gender role

Household types

Males

Preference

\section{A B S T R A C T}

This study was designed to assess differences in gender roles and preferences of female and male-headed fruit producers regarding the selection of avocado and banana varieties. Two woredas were selected purposively based on the availability of avocado and banana production trends in the woredas. Then, a model avocado and banana producing female and male-headed households were identified and about 34 households were selected randomly from both woredas. A structured questioner was used to collect primary information from the selected households. The collected data were analyzed by STATA 12 software. The obtained results indicated that the male household members exceedingly participated in land preparation (93\%), seedling preparation (90\%), transplanting $(90 \%)$ and weeding $(76 \%)$ whereas, female household members highly participated in fruit collection $(72 \%)$, transporting fruits to the market (83\%), selling the fruit (90\%) and deciding on money obtained from fruit sale $(83 \%)$. The increased participation of female household members indicated that the contribution of female-headed households on many farming activities. The major criteria considered in selection of avocado varieties were plant height $(75 \%)$, fruit size $(75 \%)$, fruit yield $(84 \%)$, fruit test $(97 \%)$ whereas, fruit yield $(91 \%)$, fruit color $(72 \%)$, fruit test $(94 \%)$ and fruit smell (53\%) were important criteria for banana varieties. There were no statistically significant differences $(P>0.05)$ in avocado and banana varieties selection criteria between female and male headed households. Therefore, breeders need not develop different avocado and banana varieties for female and male-headed producers. Gender based labor division in the study areas should be taken into consideration whenever technology is demonstrated, and farmers' training is given on avocado and banana production technologies to ensure their effective implementation.

Corresponding Author: Habtamu Gudisa Megersa

Email: habtegudisa21@gmail.com

(C) The Author(s) 2020.

\section{INTRODUCTION}

Improving Horticultural crops are providing more employment and income from the unit area of land than field crops like in Ethiopia where its populations growth are increasing at alarming rate with lower land endowments among the farmer households (EIA, 2012). The extended scope of fruits value addition, which not only provides the employment to farm families but also empower the landless households and womens in particular (Tripathi et al., 2013). The widely 
grown major types of fruit crops in Ethiopia are the tropical, subtropical and temperate categories with high potential for domestic and export market purposes including banana, avocado, mango, papaya, oranges, guava, lemons and pineapple, respectively (EIA, 2012; CSA, 2019). Consequently, the production and processing of horticultural crops mainly vegetables and fruits have been placed in the list of high priority areas by the Ethiopian government. According to EIA, (2012) reported various incentives have been provided for investors investing in this sub-sector.

However, according to CSA (2019) reported, the fruit crops grown by the farmer holders have covered only a small area of land and lower productivity in the country. Therefore, the area and number of holders practicing in fruit farming is much less than that of cereals. Out of 14474289.58 hectares of farmland allotted for crop production in meher season, only $0.83 \%$ was allotted for fruits crop production in the country. From this, banana has contributed about $55.11 \%$ of the area for fruit production followed by avocado that contributed $16.48 \%$ of the share (CSA, 2019).

Women have a considerable contribution to the agricultural sector like in Ethiopia (Nahuseny.2017). They play a crucial role particularly in the production and marketing of fruit and vegetable crops. Fruits are important crops particularly for women by generating income to fulfil their family expenditure (Lal \& Khurana.2011). However, there is a gender difference in selling and controlling income from sale of fruits depending on the volume of production and mode of marketing in the study area. When the productions of fruits are on small scale, women tend to sell and control the income obtained from the sale. While the fruit gets commercialized, the merchants tend to buy from the farm get and men tend to take over the marketing activities from womens (Lemlem \& Ranjitha, 2010). Therefore, the division of farm tasks between women and men varies according to the enterprise, the farming system, the technology used, and the wealth of the household (Lal \& Khurana. 2011). Controlling over the benefits of production also varies between women and men, partly reflecting their labor input, but also reflecting the use of produce in the home or for sale, cultural norms regarding 'women's' and 'men's' enterprises, and the dominance of men as the household head and consequently, are entitled to the most important resources like land (Ogato et al., 2009). Assessment of the need and preference of male and female farmers is crucial for the sustainable functioning of agricultural technologies. According to Lemlem et al. (2010) in Dale woreda, the tropical fruit trees mainly avocado and mango are interspersed among garden coffee as a source of shade as well as a source of fruit and cash income. However, farmers are dissatisfied with the non-improved fruit cultivars because they grow to the height of 20 meters, which makes fruit picking very difficult since they have wide canopies and extensive root systems that compete with coffee and sometimes, they do not bear fruit up to 10 years. Consequently, many farmers were removing these fruit trees and replacing them with cash crops like sugar cane and Khat.

However, various grafted avocado and banana varieties were introduced and adapted to wondo and wondo genet woredas have gave a better yield than the landrace cultivars (Un published report). The grafted avocado breaks the period of juvenility that can bear fruits three years after field transplant. These varieties are short in height for easy of fruit picking. It gives an optimum fruit size and good fruits quality. They have also the capability of better storage capacity and relatively resistant to main pests and diseases. The improved banana varieties were also introduced and well adapted to the study areas which have good production status and gave better productivity than the landrace cultivars (Un published report). These banana varieties can bear better marketable fruits sizes and quality fruits, and they are also good in keeping quality for longer distance transportation purposes.

According to Lemlem et al. (2010) women's preferences for crop varieties differ from men in different aspects. Most of the time, development of agricultural technologies do not consider gender needs and differences. Therefore, this study was designed to assess differences in role, and preferences of female and male headed producers on avocado and banana varieties for the breeders, development workers, growers and who engaged on marketing channels of the fruits for further technology improvements (varieties) and technology promotion purposes.

\section{METHODOLOGY}

\section{Description of the study areas}

Both study areas are geographically located in the great 
rift valley of Southern Ethiopia. Wondo genet is a well known for producing avocado among woredas in sidma region. Also, wondo woreda is found in west arsi zone of oromia regional state. Both woredas are commonly known by producing the cash crops (fruits, khat and sugar cane) and cereals production as mixed cropping systems (personal communication of woredas agricultural offices). Avocado and banana are an important fruit crops produced for longer periods in the areas and recently got great attention for their increased demands at nearby cities (Shashemene and Hawassa) and at the central market (Addis Ababa). A quality avocado fruit production has got especial attention in both woredas as raw material for oil extraction purpose by the newly emerging agro industrial parks.

\section{Sampling, data collection and data analysis}

The two woredas were selected purposively based on the availability of avocado and banana production potential. According to CSA (2014) about 65.78 tons of avocado and 602.92 tons of banana were reported in Sidama region, which wondo genet woreda has taken a lion share. Also, the major avocado fruits produced on 40.40 ha of land at west arsi zone was came from wondo woreda (CSA, 2014). Then, the model farmers were selected by the woredas agriculture office based on their well performance in technology uptake, increased productivity, creativity and wealth creation in the woredas. The study was targeted model producers as these farmers are assumed more informed and could evaluate technologies better than other farmers in the area. Therefore, avocado and banana producing female and male-headed model households were identified in collaboration with woreda agriculture experts. In both woredas, about 96 (68 males and 28 females headed household) model avocado and banana producers were identified for sampling frame. For this study, about 17 avocado and banana producer household heads were selected randomly from each woreda. From the selected 34 households in both woredas, about $30 \%$ of them were female-headed household farmers. Thus, the study assumed that the model farmers are more logical in variety evaluation than other farmers in the area. The pre-tested and structured questioners commented by fruit researchers was used to collect the relevant primary information
Data were collected through a demonstration of four avocados (Pinkerton, Hass, Fuerte, and Nabal) and three bananas (William, Grandlnian, and Robusta) varieties. The producers were brought to fruit farm on research demonstration site to evaluate the varieties on the farm. Then, headed household were observed the physical appearance (plant size and varietal differences) of the fruits, matured fruits and evaluate fruit test of every variety of avocado and banana that ripen properly and supplied by the researchers. After that, they were asked to rank the varieties of both fruits and tell what criteria they used to rank the varieties individually. Finally, additional information was collected from key informants to cross-check the survey results.

Finally, the collected primary quantitative data was edited and coded to SPSS and analyzed using STATA software. Descriptive statistics such as percentage and frequency were used to describe gender roles and gender differentials in avocado and banana production technologies. Also, the study employed chi-square test to evaluate gender differences in avocado and banana production and variety preference.

\section{RESULTS AND DISCUSSION}

\section{Gender role in the study areas}

Table 1 shows that the male household members highly participated in land preparation (93\%), seedling preparation (90\%), seedling transplantation $(90 \%)$ and weeding $(76 \%)$ of fruits trees, whereas, the female household members highly participated on fruit collection (72\%), fruit transportation to the market $(83 \%)$, fruit selling $(90 \%)$ and deciding on the money obtained from fruit sale (83\%). The results are consistent with the findings of Mohammed \& Abdulquadri (2012) where they found that activities such as bush clearing, land preparation, and planting of certain crops traditionally performed by men. Greater than one fifth $(21 \%)$ of the respondent households replied that male children highly involved in fruit collection and fairly participated in seedling transplanting, weeding and transporting of fruits to the marketplace. Male headed and female-headed households' significantly different only on seedling preparation and weeding. In male-headed households, all of the respondents indicated that male household members highly participated in seedling preparation, whereas in female-headed households $63 \%(\mathrm{P} \leq 0.05)$ of 
respondents indicated as male household members highly participated in seedling preparations. Similar to the seedling preparation in male headed households, $81 \%$ of the respondents indicated that male household members highly participated in weeding whereas in female headed households $63 \%$ of respondents ( $\mathrm{P} \leq 0.1$ ) indicated as male household members contributed highly to weeding. Generally, intensive participation of female household members in female-headed households was observed on many farm activities. previous studies on related issues revealed that there were cultural barriers for females to engage in many agricultural activities. For instance, Tewodaj et al. (2009) reported the restrictions even go further prohibiting women from ploughing, sowing, hoeing, and even weeding in Sidama region. Women often predominate in the cultivation of horticultural crops, especially on vegetable crop production. Crop marketing and control over revenues from the sale is often gendered differentiated and, in some cases vary with crop types. Many female farmers brought vegetables and fruits, the production which they manage to the market and retained the incomes to pay for household need.

Table 1. Labor division on fruit production in wondo and wondo genet woreda.

\begin{tabular}{|c|c|c|c|c|c|c|c|}
\hline \multirow{2}{*}{$\begin{array}{c}\text { Participation of } \\
\text { household members } \\
\text { on farm activities }\end{array}$} & \multirow{2}{*}{$\begin{array}{l}\text { Respondent } \\
\text { household } \\
\text { type }\end{array}$} & \multicolumn{4}{|c|}{ Level of participation (\%) } & \multirow{2}{*}{$\begin{array}{c}\chi 2- \\
\text { value }\end{array}$} & \multirow[b]{2}{*}{$\begin{array}{c}\mathrm{p}- \\
\text { value }\end{array}$} \\
\hline & & $\begin{array}{c}\text { Highly } \\
\text { participate }\end{array}$ & $\begin{array}{c}\text { Moderately } \\
\text { participate }\end{array}$ & $\begin{array}{c}\text { Little } \\
\text { participation }\end{array}$ & $\begin{array}{c}\text { No } \\
\text { participation }\end{array}$ & & \\
\hline \multirow{3}{*}{$\begin{array}{l}\text { Male household } \\
\text { members on land } \\
\text { preparation }\end{array}$} & Male HH & 95 & 5 & 0 & 0 & 3.043 & 0.218 \\
\hline & Female HH & 88 & 0 & 0 & 13 & & \\
\hline & Total & 93 & 3 & 0 & 3 & & \\
\hline \multirow{3}{*}{$\begin{array}{l}\text { Female household } \\
\text { members on land } \\
\text { preparation }\end{array}$} & Male HH & 5 & 38 & 14 & 43 & 2.635 & 0.451 \\
\hline & Female HH & 13 & 50 & 25 & 13 & & \\
\hline & Total & 7 & 41 & 17 & 34 & & \\
\hline \multirow{3}{*}{$\begin{array}{l}\text { Male household } \\
\text { members on seedling } \\
\text { preparation }\end{array}$} & Male HH & 100 & 0 & 0 & 0 & 8.784 & 0.012 \\
\hline & Female HH & 63 & 25 & 0 & 13 & $* *$ & \\
\hline & Total & 90 & 7 & 0 & 3 & & \\
\hline \multirow{3}{*}{$\begin{array}{l}\text { Female household } \\
\text { members on seedling } \\
\text { preparation }\end{array}$} & Male HH & 5 & 38 & 14 & 43 & 6.723 & 0.081 \\
\hline & Female HH & 38 & 25 & 25 & 13 & * & \\
\hline & Total & 14 & 34 & 17 & 34 & & \\
\hline \multirow{3}{*}{$\begin{array}{l}\text { Male household } \\
\text { members on } \\
\text { watering }\end{array}$} & Male $\mathrm{HH}$ & 81 & 10 & 0 & 10 & 4.447 & 0.217 \\
\hline & Female HH & 50 & 25 & 13 & 13 & & \\
\hline & Total & 72 & 14 & 3 & 10 & & \\
\hline \multirow{3}{*}{$\begin{array}{l}\text { Female household } \\
\text { members on } \\
\text { watering }\end{array}$} & Male $\mathrm{HH}$ & 5 & 33 & 29 & 33 & 4.249 & 0.236 \\
\hline & Female $\mathrm{HH}$ & 25 & 50 & 13 & 13 & & \\
\hline & Total & 10 & 38 & 24 & 28 & & \\
\hline \multirow{3}{*}{$\begin{array}{l}\text { Male household } \\
\text { members on } \\
\text { transplanting }\end{array}$} & Male HH & 95 & 5 & 0 & 0 & 3.392 & 0.183 \\
\hline & Female HH & 75 & 13 & 0 & 13 & & \\
\hline & Total & 90 & 7 & 0 & 3 & & \\
\hline \multirow{3}{*}{$\begin{array}{l}\text { Female household } \\
\text { members on } \\
\text { transplanting }\end{array}$} & Male HH & 0 & 57 & 14 & 29 & 5.722 & 0.126 \\
\hline & Female HH & 25 & 38 & 13 & 25 & & \\
\hline & Total & 7 & 52 & 14 & 28 & & \\
\hline \multirow{3}{*}{$\begin{array}{l}\text { Male household } \\
\text { members on } \\
\text { weeding }\end{array}$} & Male HH & 81 & 5 & 14 & 0 & 6.321 & 0.097 \\
\hline & Female HH & 63 & 25 & 0 & 13 & $*$ & \\
\hline & Total & 76 & 10 & 10 & 3 & & \\
\hline \multirow{2}{*}{$\begin{array}{l}\text { Female household } \\
\text { members on }\end{array}$} & Male HH & 5 & 43 & 24 & 29 & $6.83^{*}$ & 0.077 \\
\hline & Female HH & 38 & 38 & 25 & 0 & & \\
\hline
\end{tabular}




\begin{tabular}{|c|c|c|c|c|c|c|c|}
\hline weeding & Total & 14 & 41 & 24 & 21 & & \\
\hline \multirow{3}{*}{$\begin{array}{l}\text { Male household } \\
\text { members on Fruit } \\
\text { collection }\end{array}$} & Male HH & 19 & 24 & 5 & 52 & \multirow[t]{3}{*}{5.617} & \multirow[t]{3}{*}{0.132} \\
\hline & Female $\mathrm{HH}$ & 13 & 25 & 38 & 25 & & \\
\hline & Total & 17 & 24 & 14 & 45 & & \\
\hline \multirow{3}{*}{$\begin{array}{l}\text { Female household } \\
\text { members on fruit } \\
\text { collection }\end{array}$} & Male HH & 71 & 14 & 10 & 5 & \multirow[t]{3}{*}{1.288} & \multirow[t]{3}{*}{0.732} \\
\hline & Female HH & 75 & 13 & 0 & 13 & & \\
\hline & Total & 72 & 14 & 7 & 7 & & \\
\hline \multirow{3}{*}{$\begin{array}{l}\text { Male household } \\
\text { members on } \\
\text { transporting fruit to } \\
\text { market }\end{array}$} & Male HH & 10 & 0 & 5 & 86 & \multirow[t]{3}{*}{6.074} & \multirow[t]{3}{*}{0.108} \\
\hline & Female HH & 0 & 13 & 25 & 63 & & \\
\hline & Total & 7 & 3 & 10 & 79 & & \\
\hline \multirow{3}{*}{$\begin{array}{l}\text { Female household } \\
\text { members on } \\
\text { transporting fruit to } \\
\text { market }\end{array}$} & Male HH & 81 & 10 & 5 & 5 & \multirow[t]{3}{*}{1.675} & \multirow[t]{3}{*}{0.642} \\
\hline & Female HH & 88 & 0 & 0 & 13 & & \\
\hline & Total & 83 & 7 & 3 & 7 & & \\
\hline \multirow{3}{*}{$\begin{array}{l}\text { Male household } \\
\text { members on selling } \\
\text { fruits }\end{array}$} & Male HH & 10 & 0 & 0 & 90 & \multirow[t]{3}{*}{3.392} & \multirow[t]{3}{*}{0.183} \\
\hline & Female V & 0 & 13 & 0 & 88 & & \\
\hline & Total & 7 & 3 & 0 & 90 & & \\
\hline \multirow{3}{*}{$\begin{array}{l}\text { Female household } \\
\text { members on selling } \\
\text { fruits }\end{array}$} & Male HH & 90 & 0 & 5 & 5 & \multirow[t]{3}{*}{0.889} & \multirow[t]{3}{*}{0.641} \\
\hline & Female HH & 88 & 0 & 0 & 13 & & \\
\hline & Total & 90 & 0 & 3 & 7 & & \\
\hline \multirow{3}{*}{$\begin{array}{l}\text { Male household } \\
\text { members deciding on } \\
\text { money from fruit sale }\end{array}$} & Male HH & 19 & 0 & 24 & 57 & \multirow[t]{3}{*}{5.805} & \multirow[t]{3}{*}{0.121} \\
\hline & Female HH & 13 & 25 & 13 & 50 & & \\
\hline & Total & 17 & 7 & 21 & 55 & & \\
\hline \multirow{3}{*}{$\begin{array}{l}\text { Female household } \\
\text { members deciding on } \\
\text { money from fruit sale }\end{array}$} & Male HH & 81 & 5 & 10 & 5 & \multirow[t]{3}{*}{1.675} & \multirow[t]{3}{*}{0.642} \\
\hline & Female HH & 88 & 13 & 0 & 0 & & \\
\hline & Total & 83 & 7 & 7 & 3 & & \\
\hline
\end{tabular}

*, ${ }^{* *}$ indicates significant at $10 \%$ and $5 \%$ respectively; Source: survey result, 2015 : HH: household head.

Rank order of demonstrated avocado and banana varieties

Pearson $\chi 2$-test was used to see whether differences were observed in ranking of demonstrated banana and avocado varieties, but there was no statistically significant difference between male headed and female-headed households (Table 2). Respondents were ranked banana varieties including Robusta,
Grandlnian, and Williams as $1^{\text {st }}, 2^{\text {nd }}$ and $3^{\text {rd }}$, respectively whereas Fuerte, Pinkerton, Hass and Nabal avocado varieties were ranked 1st, $2 \mathrm{nd}$, 3rd, and 4th, respectively. Table 3 and 4 indicated the criteria used were fruit test $(97 \%)$, fruit yield (84\%), plant height $(75 \%)$ and fruit size $(75 \%)$ to rank avocado varieties whereas they considered fruit yield (91\%), fruit color $(72 \%)$ and fruit test $(94 \%)$ to rank banana varieties.

Table 2. Ranks of banana and avocado varieties compared at wondo and wondo genet woredas.

\begin{tabular}{|c|c|c|c|c|c|c|c|c|}
\hline \multirow{2}{*}{$\begin{array}{l}\text { Banana } \\
\text { varieties }\end{array}$} & \multicolumn{3}{|c|}{ Rank given in \% } & \multirow{2}{*}{$\begin{array}{l}\text { Avocado } \\
\text { varieties }\end{array}$} & \multicolumn{4}{|c|}{ Rank given in \% } \\
\hline & $1 \mathrm{st}$ & 2nd & $3 r d$ & & $1 \mathrm{st}$ & 2nd & $3 r d$ & 4 th \\
\hline Williams & 6.25 & 34.38 & 59.38 & Nabal & 0 & 18.75 & 25 & 56.25 \\
\hline Grandlnian & 9.39 & 53.13 & 37.5 & Fuerte & 62.5 & 18.75 & 12.5 & 6.25 \\
\hline \multirow[t]{2}{*}{ Robusta } & 84.38 & 12.5 & 3.13 & Hass & 0 & 12.5 & 50 & 37.5 \\
\hline & & & & Pinkerton & 40.63 & 46.88 & 12.5 & 0 \\
\hline
\end{tabular}


During informal discussion it was reported that producer's income obtained from avocado was mainly depended on fruit test, size of fruit and fruit yield. Additionally, the quality of collected fruits sometimes depended on plant height. As plant height is getting higher, the fruit collection becomes more difficult as long as fruit collection method in the survey area is handpicking or hitting the fruit using sticks or stones. There was no statistically significant difference between female and male-headed households across selection criteria of avocado and banana varieties (Table 3 and 4). This might imply that there were no particular selection criteria associated with gender difference for avocado and banana varieties.

Table 3. Criteria of ranking avocado Varieties.

\begin{tabular}{|c|c|c|c|c|c|c|c|c|}
\hline \multirow{3}{*}{$\begin{array}{l}\text { Lists of selection criteria } \\
\text { for avocado varieties }\end{array}$} & \multicolumn{6}{|c|}{ Response by household type (\%) } & \multirow{3}{*}{$\chi 2$-Value } & \multirow{3}{*}{ p-value } \\
\hline & \multicolumn{2}{|c|}{ Male headed } & \multicolumn{2}{|c|}{ Female headed } & \multicolumn{2}{|c|}{ Total } & & \\
\hline & Yes & No & Yes & No & Yes & No & & \\
\hline Yield & 87 & 13 & 78 & 22 & 84 & 16 & 0.41 & 0.520 \\
\hline Fruit color & 9 & 91 & 11 & 89 & 9 & 91 & 0.04 & 0.830 \\
\hline Fruit size & 74 & 26 & 78 & 22 & 75 & 25 & 0.05 & 0.820 \\
\hline Plant height & 83 & 17 & 56 & 44 & 75 & 25 & 2.53 & 0.110 \\
\hline Maturity period & 26 & 74 & 11 & 89 & 22 & 78 & 0.85 & 0.360 \\
\hline Fruit test & 100 & 0 & 89 & 11 & 97 & 3 & 2.64 & 0.100 \\
\hline Fruit shape & 9 & 91 & 0 & 100 & 6 & 94 & 0.83 & 0.360 \\
\hline
\end{tabular}

Table 4. Criteria for ranking banana varieties.

\begin{tabular}{|c|c|c|c|c|c|c|c|c|}
\hline \multirow{3}{*}{$\begin{array}{l}\text { Lists of selection criteria for } \\
\text { banana varieties }\end{array}$} & \multicolumn{6}{|c|}{ Response by household type (\%) } & \multirow{3}{*}{$\begin{array}{l}\chi 2 \text { - Value } \\
\text { statistics }\end{array}$} & \multirow{3}{*}{ P-value } \\
\hline & \multicolumn{2}{|c|}{ Male headed } & \multicolumn{2}{|c|}{ Female headed } & \multicolumn{2}{|c|}{ Total } & & \\
\hline & Yes & No & Yes & No & Yes & No & & \\
\hline$\overline{\text { Yield }}$ & 96 & 4 & 78 & 22 & 91 & 9 & 2.43 & 0.119 \\
\hline Fruit color & 70 & 30 & 78 & 22 & 72 & 28 & 0.22 & 0.642 \\
\hline Fruit size & 22 & 78 & 0 & 100 & 16 & 84 & 2.32 & 0.128 \\
\hline Plant height & 22 & 78 & 11 & 89 & 19 & 81 & 0.48 & 0.489 \\
\hline Maturity period & 35 & 65 & 44 & 56 & 37 & 63 & 0.26 & 0.612 \\
\hline Fruit test & 96 & 4 & 89 & 11 & 94 & 6 & 0.51 & 0.477 \\
\hline Fruit shape & 0 & 100 & 0 & 100 & 0 & 100 & - & - \\
\hline Fruit smell & 48 & 52 & 67 & 33 & 53 & 47 & 0.92 & 0.337 \\
\hline
\end{tabular}

\section{CONCLUSION AND RECOMMENDATIONS}

The preferences of male and female-headed households on avocado and banana varieties were not statistically different. Therefore, breeders need not develop different avocado and banana varieties for female and male farmers. There was gender based labor division in the study areas, which should be taken into consideration whenever technology is demonstrated and related farmers training given on avocado and banana planting, weeding, harvesting, and post-harvest management as this could affect production and marketing efficiency differently in male and femaleheaded producers.

\section{CONFLICT OF INTEREST}

The authors declare that there is no conflict of interest regarding the publication of this paper.

\section{ACKNOWLEDGMENTS}

We would like to thank the Ethiopian Institute of Agricultural Research (EIAR) for sponsoring our study and Wondo Genet Agricultural Research Centre (WGARC) for facilitating the study. We are also thankful for wondo and wondo genet woredas for facilitation and provision of farmers to this case study. Above all, many thanks go to all member staff of WGARC for their unreserved support in different aspects to execute our activity successfully.

\section{REFERENCES}

CSA (Central Statistical Authority). 2014. Mehir season report on Area and production of major crops, Addis Ababa, Ethiopia.

CSA (Central Statistical Authority). 2019. Mehir season report on Area and production of major crops, 
Addis Ababa, Ethiopia.

EIA (Ethiopian Investment Agency). 2012. Investment opportunity profile for the production of fruits and vegetables in Ethiopia.

Lal, R., and Khurana, A. 2011. Gender issues: The role of women in agriculture sector. International Journal of Business Economics Management Research, 1(1): 29-39.

Lemlem, A. and P. Ranjitha, 2010. Strategies in increasing women's participation in commodity value chain development: Experiences from IPMS (Improving Productivity and Market Success of Ethiopian Farmers Project), ILRI (International Livestock Research Institute), Addis Ababa, Ethiopia.

Lemlem A., C. Bishop-Sambrook, R. Puskur and E. Tesema. 2010. Opportunities for promoting gender equality in rural Ethiopia through the commercialization of agriculture," IPMS (Improving Productivity and Market Success of Ethiopian Farmers Project), ILRI (International Livestock Research Institute), Addis Ababa, Ethiopia.

Mohammed, B. T., and Abdulquadri, A. F. 2012.
Comparative analysis of gender involvement in agricultural production in Nigeria, Journal of Development and Agricultural Economics, 4(8): 240-244.

Nahusenay A. 2017. The Role Rural Women on Agricultural Labor Conscription in Ethiopia: the case of Delanta district, South Wello zone. EC Nutrition, 6 (4):144-155

Ogato, G. S., Boon, E. K., \& Subramani, J. 2009. Gender roles in crop production and management practices: A case study of three rural communities in Ambo District, Ethiopia. Journal of human ecology, 27(1): 1-20.

Tewodaj M., Marc J. Cohen, R. Birner, M. Lemma, J. Randriamamonjy, F. Tadesse and Z. Paulos. 2009. Agricultural Extension in Ethiopia through a Gender and Governance Lens, Ethiopia Strategy Support Program 2 (ESSP2), Discussion Paper No. ESSP 2007, (IFPRI) International Food Policy Research Institute, Addis Ababa, Ethiopia.

Tripathi, N. B., and M. Prustry. 2013. Gender Preferences for Cultivation of Horticultural Crops, Journal of Engineering, Computers \& Applied Sciences. (JEC\&AS), 2(10).

Publisher's note: EScience Press remains neutral with regard to jurisdictional claims in published maps and institutional affiliations.

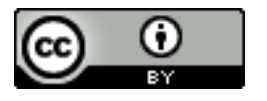

Open Access This article is licensed under a Creative Commons Attribution 4.0 International License, which permits use, sharing, adaptation, distribution and reproduction in any medium or format, as long as you give appropriate credit to the original author(s) and the source, provide a link to the Creative Commons license and indicate if changes were made. The images or other third-party material in this article are included in the article's Creative Commons license, unless indicated otherwise in a credit line to the material. If material is not included in the article's Creative Commons license and your intended use is not permitted by statutory regulation or exceeds the permitted use, you will need to obtain permission directly from the copyright holder. To view a copy of this license, visit http://creativecommons.org/licenses/by/4.0/.

(C) The Author(s) 2020 . 